\title{
Review
}

\section{Evaluation mathematical models in SSCM and Gap analysis}

\author{
Zahra Ghorbani Ravand * and Prof. Qi Xu
}

Department of logistics and electronic commerce, Glorious Sun School of Business and Management, Shanghai Donghua University, China

* Correspondence: $415021 @$ dhu.edu.cn;

\begin{abstract}
:
The main purpose of this paper is to present a comprehensive view of the application mathematical models in the designing and implementing SSCM beside to solving problems and making decision. The research questions are: what mathematical models are used for designing and implementing sustainable supply chain management, how to use them, which industries implemented in, what modules of SSCM depth in and finally finding the gaps of researches. The methodology of research is Systematic Literature review through peer review papers which are published in high ranking journals. In this paper, First, we search all papers through scientific data bases like Scopus, science direct, MDPI, Springer, Google Scholar, then, screening papers based on the criteria such as subject of paper, journals impact factor which is published in-should be peer review journal- and relative content of the papers. Finally, we selected 245 papers with three steps screening through 2806 papers that they have enough quality and relative to our research goals for context analysis. Through context analysis, first we categorized the information of the papers and drew the current situation of researches in the framework of our topic. Then, we evaluate and compare the goals of sustainability and current situation and found the gapes, then, offered new suggestions like implementing SSCMs models in pollutant industries like casting industry, Heavy industry, coal Industry and so on. On the other hand, there are gaps in researches in some modules of SSCM such as packaging, designing products, etc.
\end{abstract}

Keywords:

SSCM; Mathematical Model; Systematic Literature Review; SSCM Modules; Sustainable Development Goals; Gap analysis.

\section{List of acronyms}

2E-LRP: 2(Two) Echelon Location Routing Problem

ACO: Ant Colony Optimization

AHP: Analytic Hierarchy Process

AI: Artificial Intelligence

AMOVNS: Adapted Multi Objective Variable Neighborhood Search

ANOVA: one-way statistical analysis

ANP Technique: Analytic Network Process Technique

ANP: Analytic Network Process

BMW: Best Worst Method 
BOP: Base Of the Pyramid

CI: Composite Indicator

CLSC: Closed Loop Supply Chain

CSF: Critical Success Factor

CSR: Corporate Social Responsibility

CSS: Corporate Sustainability Standard

DC: Dynamic Capabilities

DEA: Data Envelope Analysis

DEMATEL: DEcision-MAking Trial and Evaluation Laboratory

DMUs: Decision Making Units

EFP: Environmental Friendly Products

ELECTRE: ELimination Et Choix Traduisant la REalité

EOQ: Economic Order Quantity

EPQ: Economic Production Quantity

ERM: Enhanced Russell Measure

EUFP: existing environmental unfriendly product

EWH: European Waste Hierarchy

FIS: Fuzzy Inference System

FMEA: Failure Mode and Effects Analysis

FSSD: Framework for Strategic Sustainable Development

GA: Genetic Algorithm

GLM: Green Logistic Management

GRI: Global Reporting Initiative

GSCM: Green Supply Chain Management

GVC: Global Value Chain

IE: Industrial Ecology

IFS: Intuitionistic Fuzzy System

IS: Industrial Symbiosis

ISM: Interpretive Structural Modeling

ISM: Interpretive Structural Modeling 
KPI: Key Performance Indicators (KPIs)

LCA: Life Cycle Assessment

LCIA: Life Cycle Inventory Assessment

LRPTW: Location Routing Problems with Time Windows

LSP: Leader Selection Procedure

MCDM: Multiple-Criteria Decision-Making

MHPV: Multi-objective Hybrid Metaheuristic Algorithm

MILP: Mixed Integer Linear Programming

MINLP: Mixed Integer Non Linear Program

MLH: maximum likelihood estimation

MOGA: Multi-Objective Genetic Algorithm

MOMIP: Multi Objective Mixed-Integer Programming

MOOP: Multi Objective Optimization Problem

MOPSO: Main Loop Particle Swarm Optimization

MOPSO: Multi Objective Particle Swarm Optimization

MP: Mathematical Programming

MRIO: Multi-Region Input-Output

NGO: Non-Government Organization

NIS: Negative Ideal Solution

NRGA: Non-dominated Ranked Genetic Algorithm

NSERC: Natural Science and Engineering Research Council

NSGAII: Non-dominated Sorting Genetic Algorithm II

OEM: Original Equipment Manufacturer

PIS: Positive Ideal Solution

QFD: Quality Function Developed

RDT: Resource Dependence Theory

RFID: Radio Frequency Identification Technology

SA: Simulated Annealing

SCM: Supply Chain Management

SCND: Supply Chain Network Design 
SEM: Structural Equation Modeling

SMP: Sustainable Manufacturing Practice

SNSF: Swiss National Science Foundation

SPL: Sustainable Production Line

SS: Scatter Search

SSCM: Sustainable Supply Chain Management

SSHRC: Social Science and Humanities Research Council

SWOT: Strength, Weakness, Opportunity and Threat

TBL: Triple Bottom Line

TFN: Triangular Fuzzy Number

TOPSIS: Technique for Order of Preference by Similarity to Ideal Solution

TS: Tabu Search

TSP Model: Two Stage Programming Model

VIKOR: VlseKriterijuska Optimizacija I Komoromisno Resenje

VRP: Vehicle Routing Problems

WCED: World Commission on Environment and Development

\section{Introduction}

SSCM refers to implementing all sustainable goals via Triple Bottom Line which are economic, environmental and social dimensions. In parallel, SSCM define as management of information, capital, and materials through cooperation and collaboration of Supply chain partners, stakeholders, customers, and people [1]. In two last decades the numbers of scholars and academic researchers made different conceptual and mathematical models for SSCM and used a several of tools for decision makings. Some papers evaluated sustainability in the wide range of supply chain refers to the area of research like development and developing countries and made some mathematical models, rules or new suggestions for developing countries [2]; [3]; [4]; [5]. Because of rapid changing in environmental conditions and a number of alarming for warming world and environment protection, recently, the scholars and researchers take more attention on environment dimension of sustainability and green sustainable supply chain management [6]; [7]; [8]; [9]. Unfortunately, the social aspect in majority of papers underrepresented in comparison with economic and environmental factors [10]. In addition, Governments and new policies set some rules for carbon cap and emission carbon for factories, suppliers and logistics companies [11]. Although, there are some suggestions to governments to define subsides for environmental friendly products in order to controlling pollution and carbon cap [12].

Through literature review, we found that papers present different kind of literature review and state of art for SSCM such as: offering various tools and methods for SSCM performance measurement [13]; [14]; analysis evolution SSCM trends across industries and economics [15]; evaluation different opportunities and challenges for designing and implementing SSCM [16]; [17]; Mathematical and measurement tools for organization performance [18], evaluated the concept and thematic scope in theoretical point of view and in relation to its practical implementation [19], the role of governments for renewable energy usage [20], Using cleaner Production method for large energy intensive industries [21], Applying and implementing triple bottom line in SSCM [22]; [23] and the ways for quantitative social impacts [24]. 
In this paper, we evaluate different mathematical models which are used in SSCM in order to decision support system, design and modeling, implementing, development, Environmental protection and social responsibility. First we define the sources of recently researches from 2008 to now, then we find proper papers and analysis the current researches which are related to our subjects. After that, we define a target for achievement to an ideal SSCM structure with use of 2021 Sustainable Development Goals [25]. Finally, we compare the current situation and Target, the results of comparison are shown the gaps.

\section{Materials and Methods}

In this paper, we use different researches, papers, protocoles and manifests which are related to Sustainability, SSCM and future plan of the world. As it shows in Figure (1), we use a systematically paper review and gap analysis in our research.

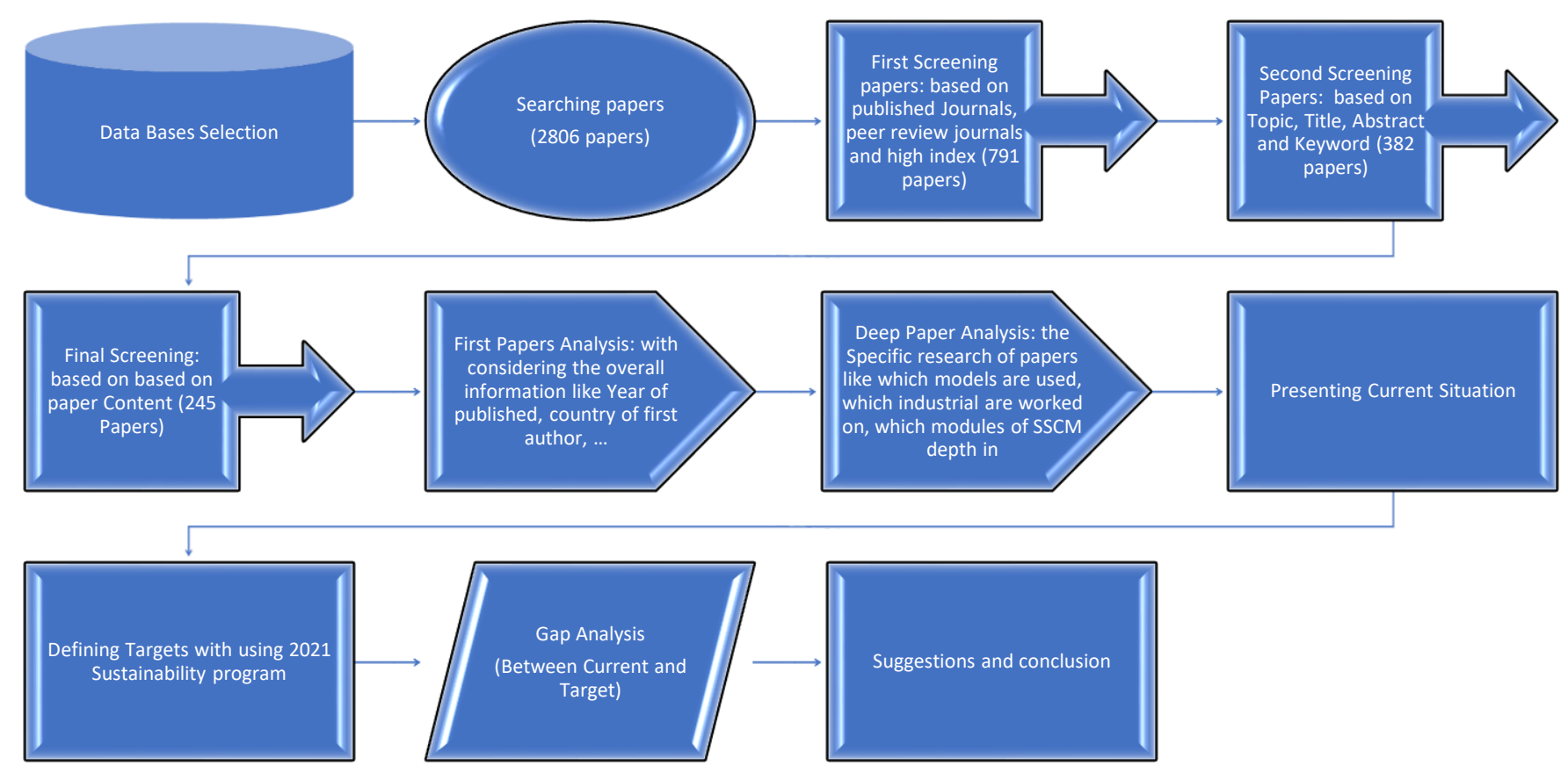

Figure 1: The flow chart of the Research Methodology

2.1. First: choosing valid data bases: Scopus, Science Direct, Emerald, Springer, Taylor \& Francis, JSTORE, Wiley Online library, SAGE Publication.

2.2. Second: searching and gathering papers through the key words which are "SSCM" + "Mathematic", "Sustainability Supply Chain Management" + "math", "SSCM" + "Model", "Sustainability" + "Supply chain" + "math". In this step, the number of papers with mentioned key words are 2806. Also, Only papers written in English considered and, The range of data was the year from 2008 to May 2021.

2.3. Third: Screening papers in three steps;

$>\quad$ Step one of screening is to evaluation the valid journals with criterias like peer review, ranking and index; After finishing first screening, the number of papers are 791. These papers are published in peer review, high index journals. $>\quad$ Step two of screening is to evaluation the topic and abstract of journals; After finishing the second screening, the number of papers are 382. These papers are selected based on the relevant topic and abstract to the objectives of paper and research questions.

$>\quad$ Step Three of Screening is to use the systematically content analysis for selecting relevant papers. After final selection and content analysis, the number of papers are 245 which are published in international, peer review and high index journals, have relevant topic, abstract, keyword and content with the research objectives and questions. 
2.4. Forth: definning the target for SSCM according to 2021 Sustainabile Development Goals [25]. Based on Sustainable Development Goals, Goals numbers 9 and 12 is related to our topic. For every module of SSCM and partners we define the Target for research.

2.5. Fifth: with using gap analysis, find the gaps in several categories like Industries, module of SCM and responsibilities of different partners.

\section{Review and Results}

For review and analysis selected papers, we categorized selected papers in four categories. Every categories, first the existing situation of papers and researches are presented, then evaluate and analysis the gaps.

$>$ Category one: overall information like as Year of published, Journals, Country of first author, Industrial, Dimension of SSCM;

Category two: SSCM modules that the papers depth in;

$>$ Category Three: Mathematical models and methods which are used for SSCM;

$>$ Category Four: The roles of parties in SSCM modeling.

After reviewing and analysis the papers and categorizing in four main categories, the existing situation of recently researches is recognized. These categories present the current situation of researches of mathematical models which are used for SSCM. For gap analysis and propose new idea, the depth of information in this step is very important. Then, we analysis the papers in different point of view.

\subsection{Category one: Overal information}

This Category analysis the overal information of the papers like year, journals, country, Industrial and dimension of SSCM. The figure 2 shows the distribution of papers between 2008-End of March 2021 and presents the numbers of papers which are published in every year.

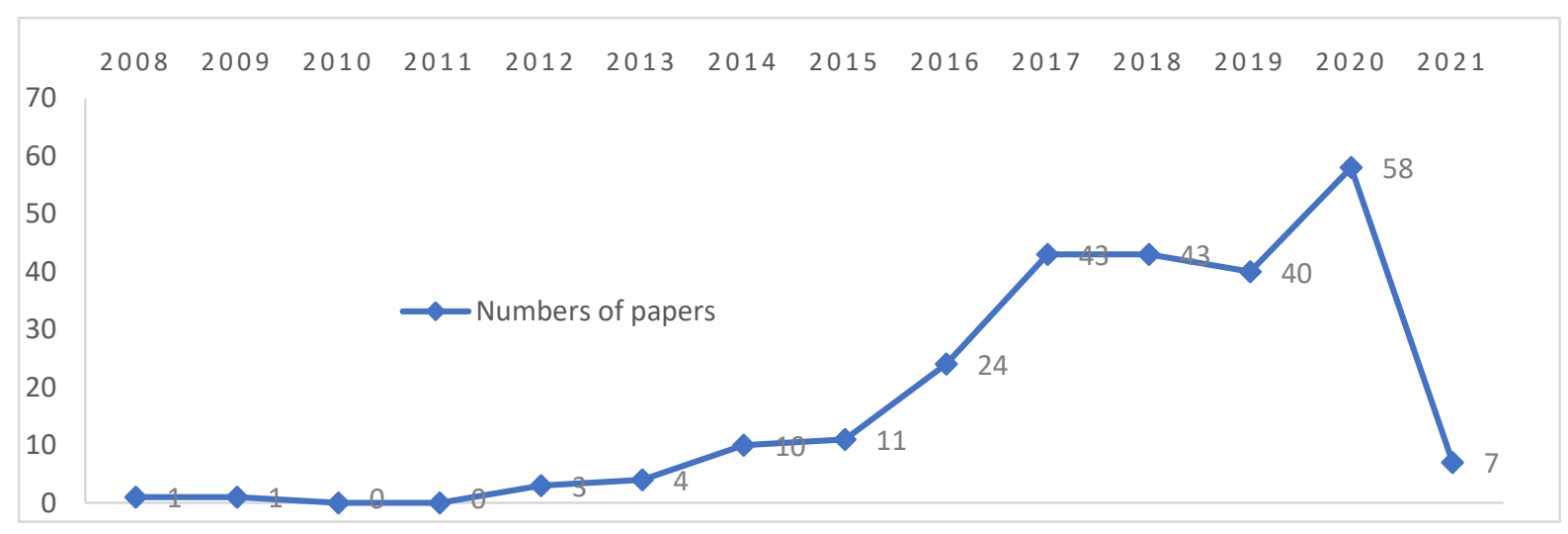

Figure 2: Distribution of published papers per year from 2018 to the end of March 2021

The curve (Figure 2) presents that the quantity of papers increases every year from 2012 to 2017 . As clearly seen in figure 2, the quantity of papers in 2017, 2018 and 2019 are near together and after that in 2020, the quantity is increased. Overall, it means that there are enough interests for researchers to do research on applications of mathematical methods and using different tools and methods for modeling and solving problems in the field of sustainability and SCM.

The Figure 3 shows the distribution of journals which published more than two relative papers. 


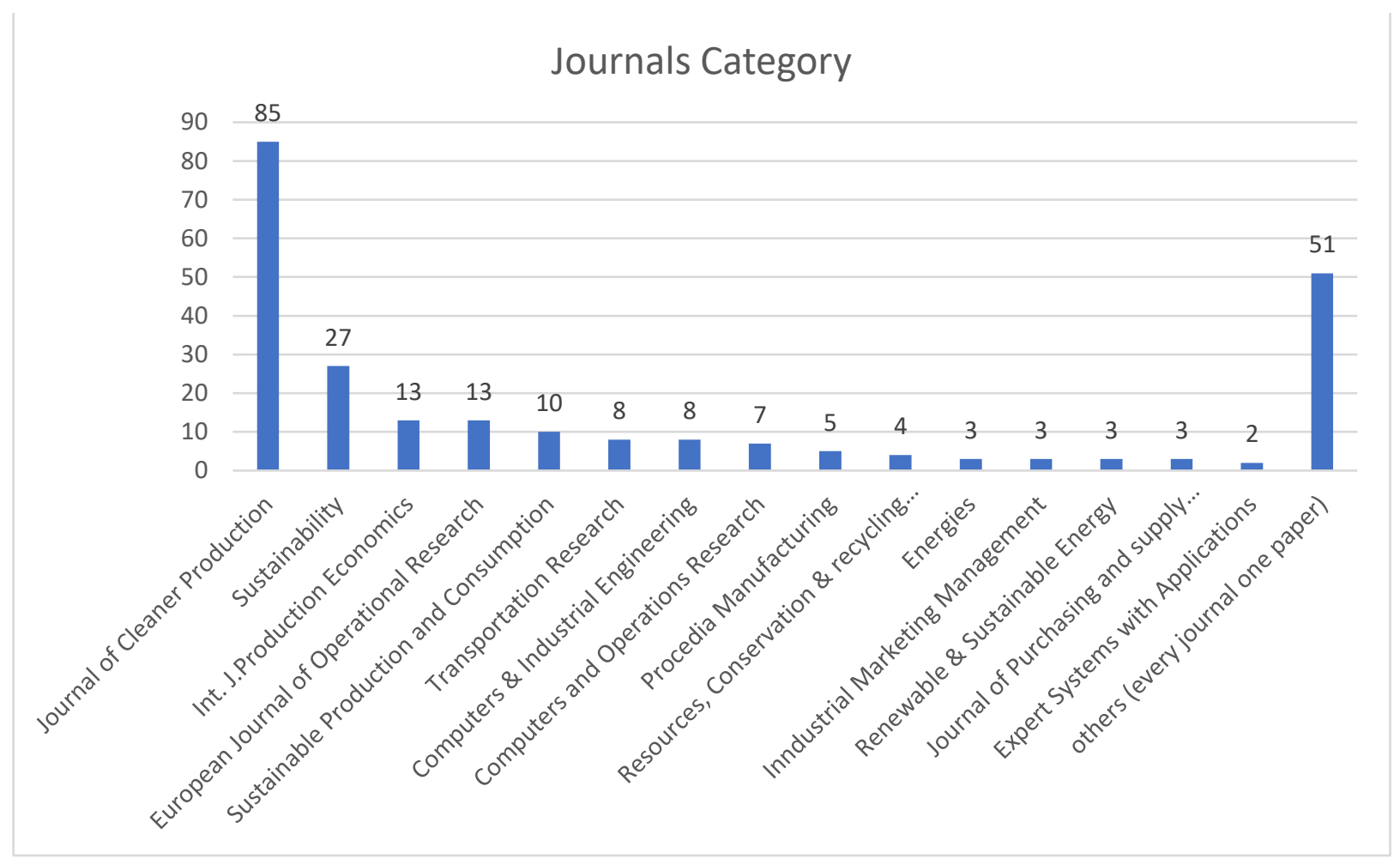

Figure 3: Number of papers by Journal

As clearly seen in the figure 3, the cleaner production Journal has the most quantity of papers in the territory of our research by 85 papers. After that the sustainability Journal is the second journal which published relative papers by 27 . The 51 journals published only one paper related to the research scope.

The Figure 4 shows the numbers of published papers per country of author. The papers which have several authors from several countries, only the country of first authors are considered.

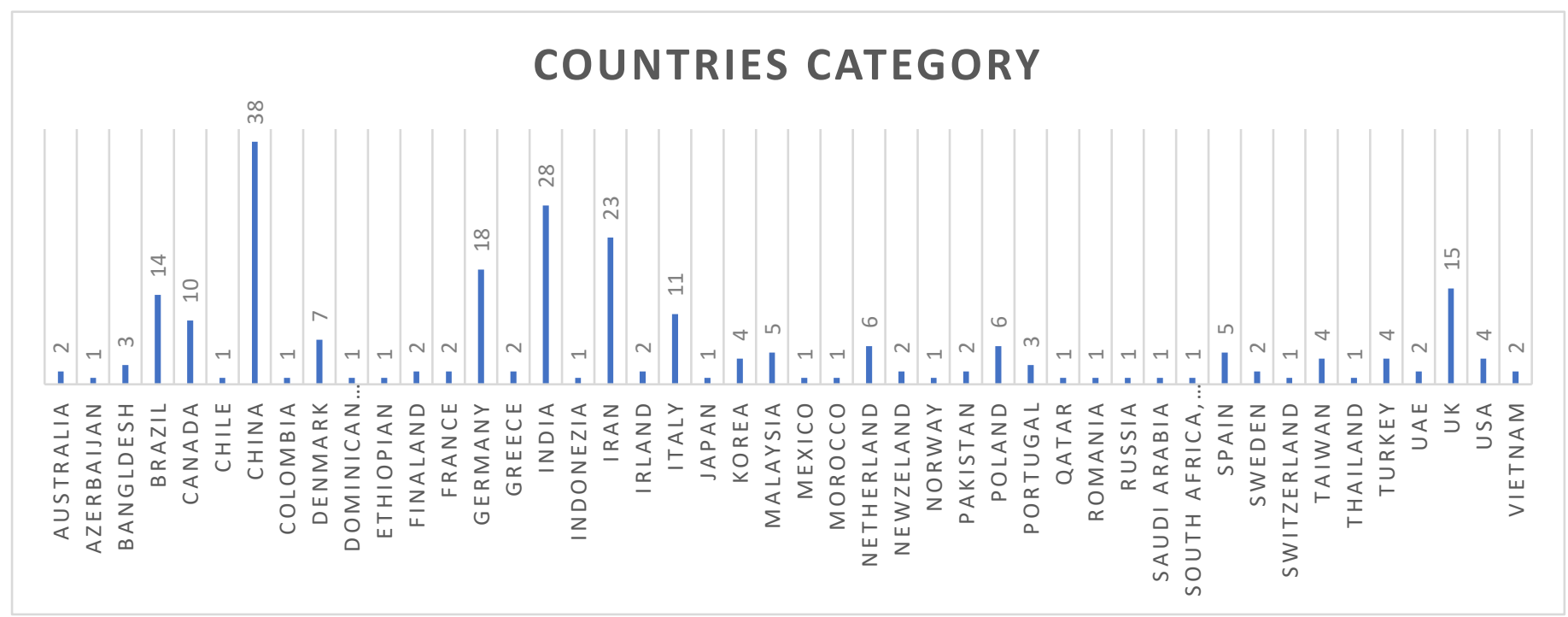

Figure 4: The quantity of papers per first author's country 
The most papers are published by authors from china by 38 papers. As it is clear, china pollution is very serious and because of that there is a big effort from Chinese government side for finding solutions. After china, India, Iran and Germany are 28, 23, and 18 papers respectively.

Figure 5 presents the mathematical models which are implement in industries as case study. This statistics help us to find gaps in the industries that there is no research for them. Although, we can use the existing research for development.

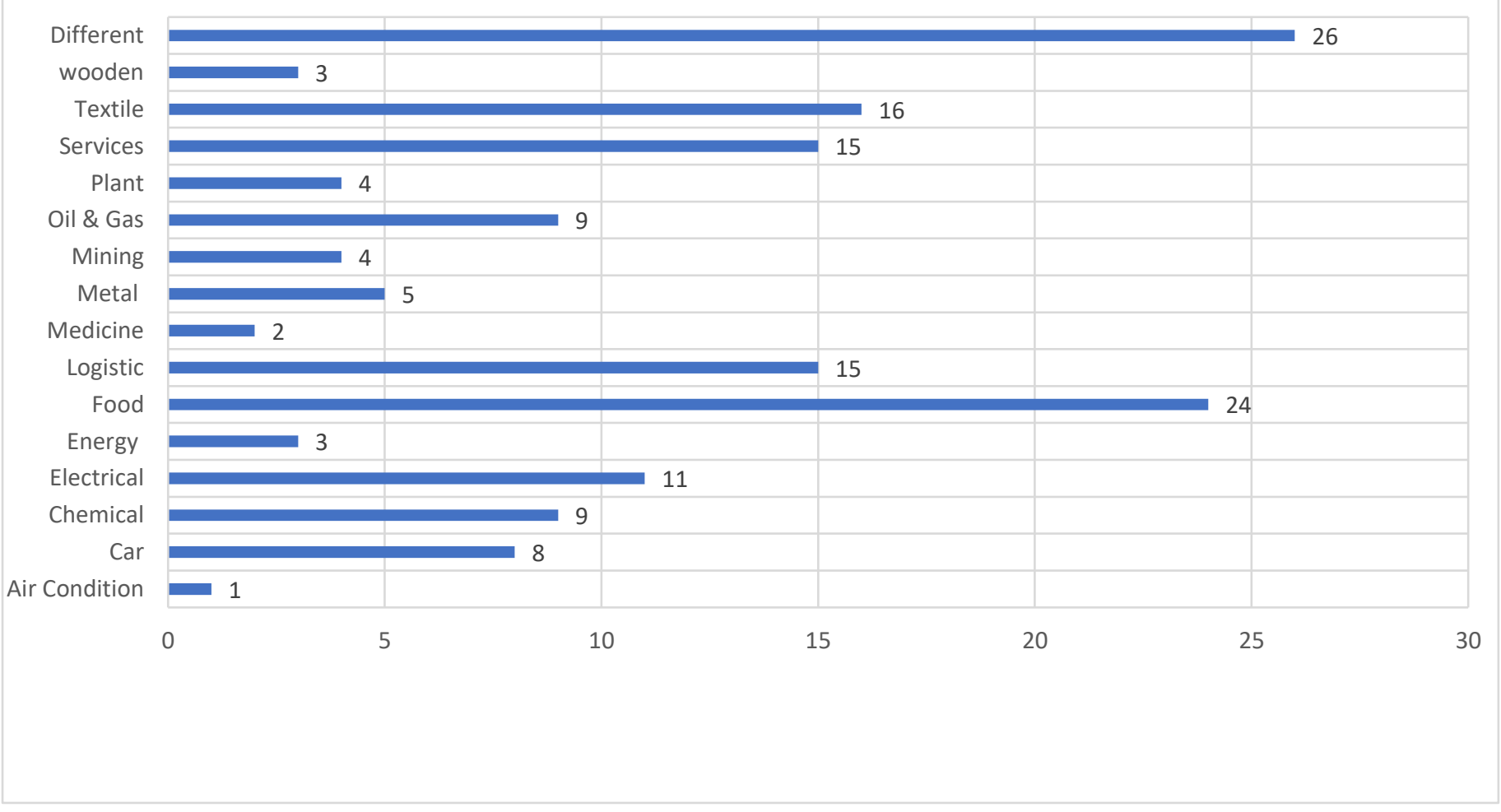

Figure 5: The number of papers for each Industry

The researches had more attention on food industry and maximum papers and case studies are related to Food industry by 24 papers. Then the papers in the field of Textile, Services, Logistics, Electrical, Chemical and oil and Gas industries are 16,15,15,11,9, and 9 respectively. The different is refer to the other papers which are concentrated in several industry or case study or services.

Figure 6 presents the quantity of each papers which are distinguished in every dimensions of SSCM: Social, Economic and environmental. 


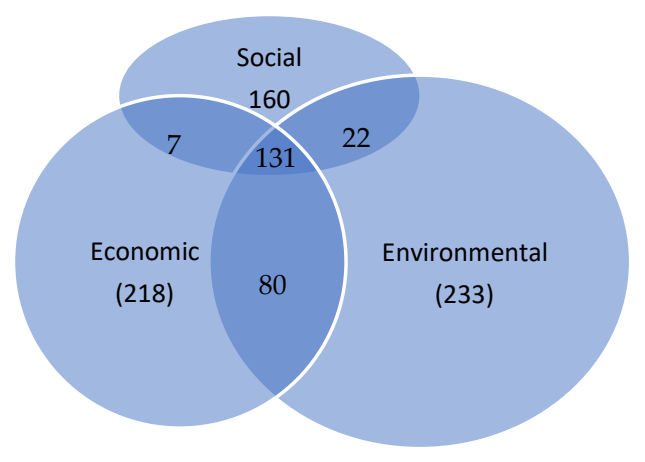

Figure 6: The quantity of papers per SSCM Dimensions

Figure 6 illustrate the number of papers for dimensions of sustainability which are social, environmental and economic in SCM modeling. The most striking feature of the picture seems to the environmental dimension is more interesting in the researches. However, the social dimension is needed to be research more.

\subsection{Category two: Modules of SSC and papers for every category}

First of all, the modules of SSCM are defined. For definning SSCM Modules, we defined level one of process of SSCM in two kind of process: Main Process and Supporting process. The main process are the process to involve for producing the products and delivery to customers and recycling the products for protecting environment. The supporting process are the process which are needed for the best services to customers and social responsibility or needed for better performance in main process. The main and supporting process devided to modules. The figure 7 shows the modules of SSCM modeling that it presents level two of process.

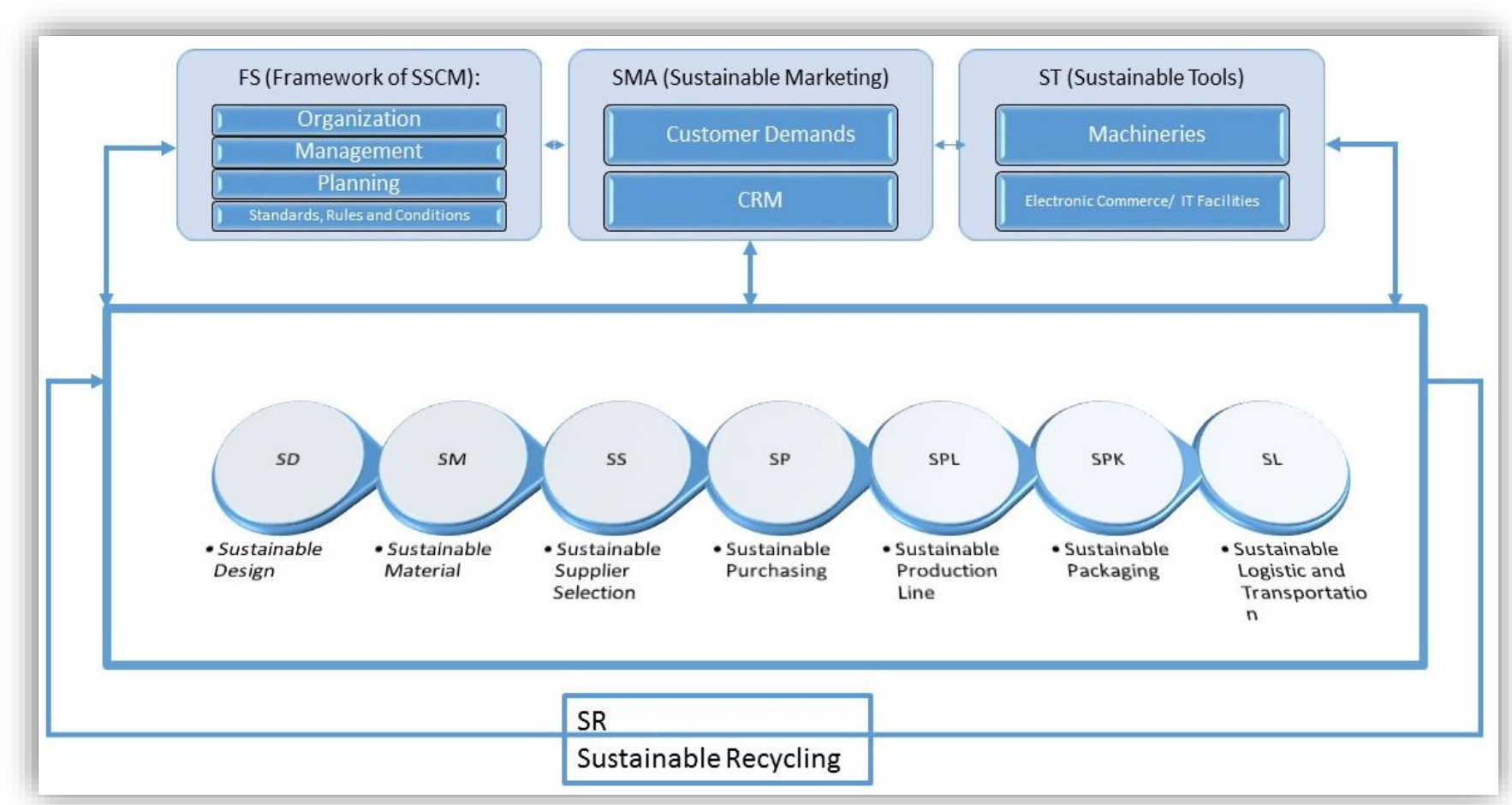

Figure 7: The modules of SSCM 
As it can clearly seen in figure 7, The modules of main process are SD, SM, SS, SP, SPL, SPK, SL, and SR. And modules for supporting process are FS, SMA, and ST. For supporting process and modules, we define sub-modules as show in Figure 7.

For every modules, we have some papers which are depth in. Figure 8 shows the number of papers for every modules of SSCM. The big amont of papers are focused on model FS which are related to Structure, Frame work, Management, Standards, Rules and conditions, planning and organization for SSCM modeling.

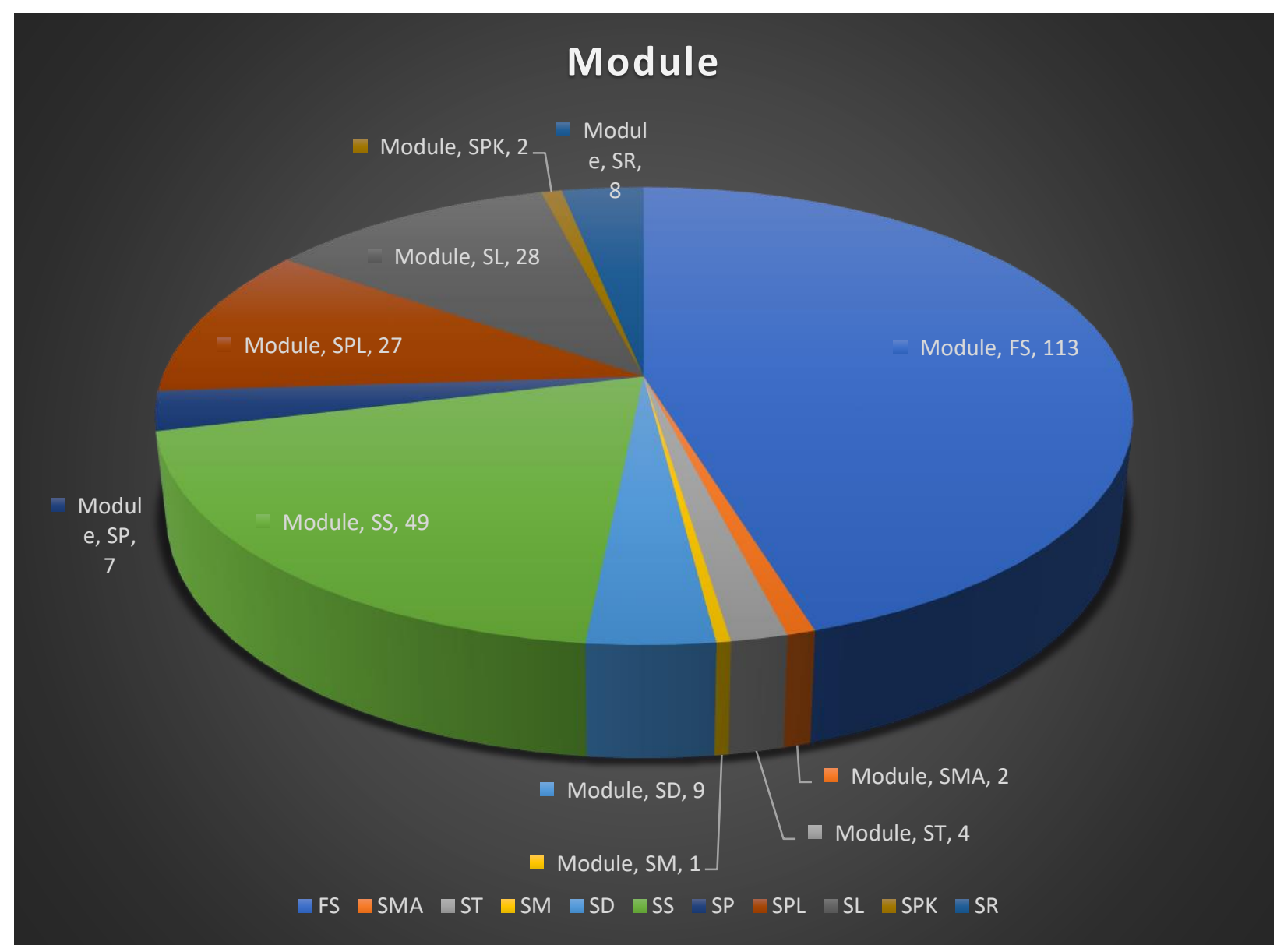

Figure 8: The number of papers for every modules

The figure 8 indicates the number of papers which are depth in every modules of SSCM. The most notable feature of the graph concerns the less research on some important modules like SM, SPK and SP. These pile represents the gap of researches clearly.

3.3. Category Three: Mathematical Models and methods which are used for SSCM 


\section{MATHEMATICAL MODELS AND METHODS IN SSCM}

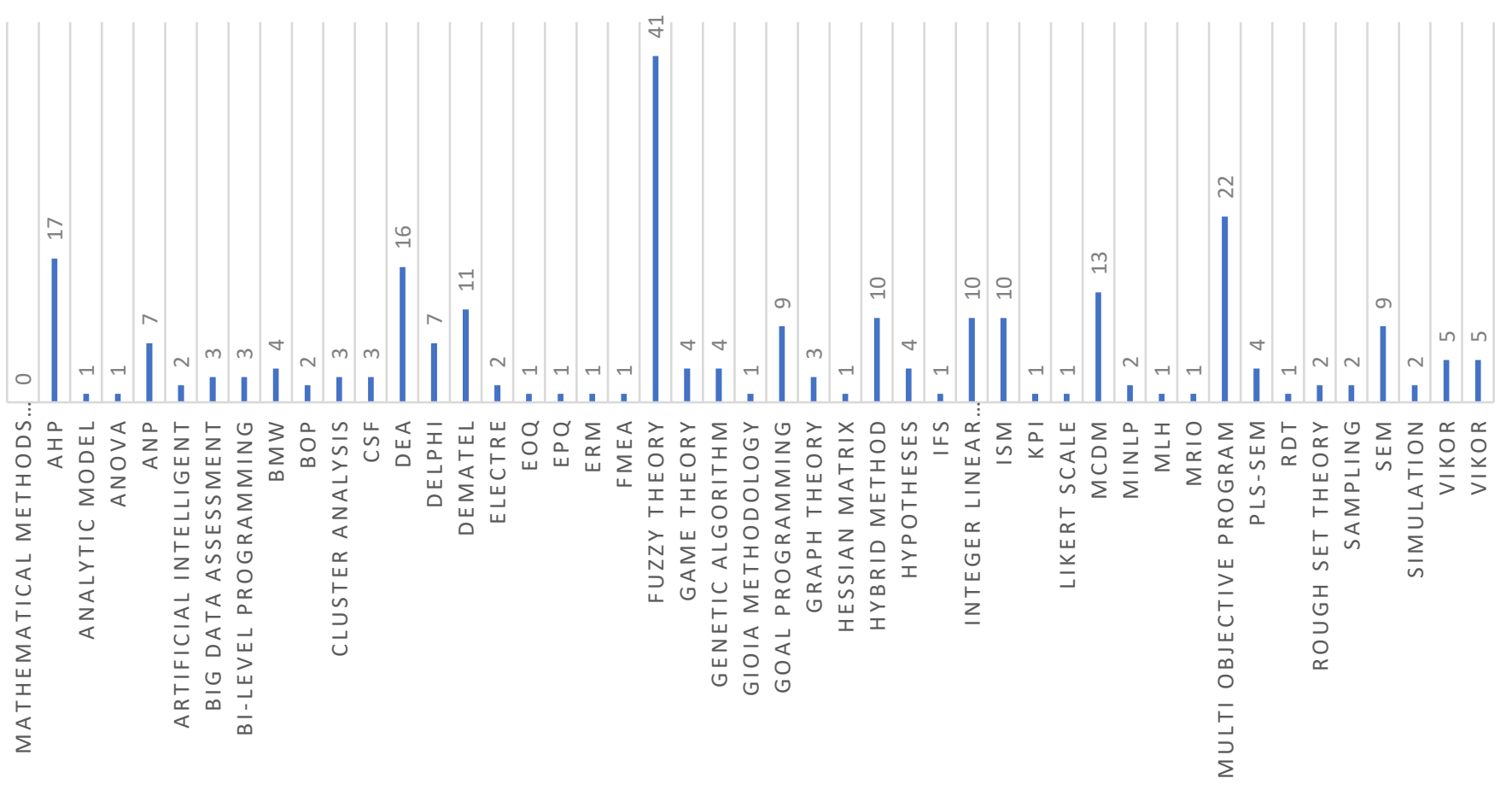

Figure 9: The chart of mathematical models for SSCM

The figure 9 represents the mathematical tools and models which are used for making SSCM modeling. As a general overview, it can be said that the Fuzzy theory is a usefule mathematical method for making models and solving problems in SSCM models. Fuzziy theory is used as a single method for solving problem or combine with other mathematical models for making SSCM models. After that, the multi objective programming is the second mathematical model which is used for SSCM. One of the main reason of used multi objective programming is thriple bottom line in SSCM and need to offer the optimum solutions for supporting decision making.

Table 1 shows the authors who have more researchs and papers for using mathematical models and methods in SSCM modeling and problem solving. As it can clearly seen, they also used fuzzy theory with combination of other methods, Multi-Objective Programming as a mathematical methods and models in their papers more than other methods. Although, Supplier Selection module and Framework of Sustainable SCM are more intresting for authors and they focused on these two modules more than others.

Table 1 shows the authors who have more than one research in the fireld of application mathematical models for SSCM modeling, solving problems and decision suport system. Prof. Kannan Govindan, Prof. Devika Kannan, and Prof. Stefan Seuring have the more researches in this field.

Table 1: The Authors who have more researchs in the field of mathematical application for SSCM

\begin{tabular}{lllllll}
\hline $\mathbf{R}$ & Authors & As First & As Co- & Models which are used & Mod & Ref. \\
ule & \\
$\mathbf{a}$ & & Author & Author & & & \\
$\mathbf{w}$ & & & & & Multi-Objective Programming & SS, $\quad$ [26]; [27]; [28]; [29] \\
\hline $\mathbf{1}$ & Huiping & 4 & - & & SPL, \\
& Ding & & & & FS \\
\hline
\end{tabular}




\begin{tabular}{|c|c|c|c|c|c|c|}
\hline 2 & $\begin{array}{l}\text { Kannan } \\
\text { Govinda } \\
\mathrm{m}\end{array}$ & 3 & 6 & $\begin{array}{l}\text { integrated fuzzy AHP-VIKOR approach- } \\
\text { based, Multi Criteria Decision Making } \\
\text { (MCDM) tool } \\
\text { a combination of Analytical, Hybrid MCDM, } \\
\text { DEMATEL-ANP (DANP). Fuzzy Delphi } \\
\text { Method, Multiple-objective optimization } \\
\text { Vehicle routing problem Swarm intelligence } \\
\text { algorithms } \\
\text { hybrid of genetic algorithm (GA) and VNS as } \\
\text { the benchmark algorithm, Augmented 3- } \\
\text { constraint (AUGMECON) method }\end{array}$ & $\begin{array}{l}\text { FS, } \\
\text { SS, } \\
\text { SL, } \\
\text { SD, } \\
\text { SM } \\
\text { A }\end{array}$ & $\begin{array}{l}{[17] ;[30] ;[31] ; \quad[32] ;[33] ;[34] ;[35] ;} \\
{[36] ;[37]}\end{array}$ \\
\hline 3 & $\begin{array}{l}\text { Devika } \\
\text { Kannan }\end{array}$ & 3 & 5 & $\begin{array}{l}\text { Structural Equation Modelling (SEM), the } \\
\text { combination of the Fuzzy DELPHI } \\
\text { approach and the hybrid MCDM techniques, } \\
\text { Critical success factor (CSF) theory, Fuzzy set } \\
\text { theory, TOPSIS, Triangular fuzzy number, } \\
\text { sensitivity analysis, Continuous } \\
\text { approximation CA, Stochastic mixed integer } \\
\text { programming SMIP, Fuzzy mixed integer } \\
\text { programming FMIP, Mixed integer non- } \\
\text { linear programming (MINLP), Mixed integer } \\
\text { linear programming, Hybrid MCDM, } \\
\text { DEMATEL-ANP (DANP). Fuzzy Delphi } \\
\text { Method, analytical hierarchical process } \\
\text { (AHP)- VIKOR }\end{array}$ & $\begin{array}{l}\text { FS, } \\
\text { SS, } \\
\text { SD, } \\
\text { SR, } \\
\text { SL }\end{array}$ & [38]; [39]; [6]; [40]; [22]; [32]; [34]; [36]; \\
\hline 4 & $\begin{array}{l}\text { Stefan } \\
\text { Seuring }\end{array}$ & 2 & 3 & base-of-the-pyramid (BoP), & FS & [41]; [35]; [42]; [1]; [43]; \\
\hline 5 & $\begin{array}{l}\text { Payman } \\
\text { Ahi }\end{array}$ & 2 & - & $\begin{array}{l}\text { probabilistic approaches to SSCM } \\
\text { performance measurement }\end{array}$ & FS & [44]; [14] \\
\hline 6 & $\begin{array}{l}\text { Moham } \\
\text { mad } \\
\text { Izadibak } \\
\text { hsh }\end{array}$ & 2 & - & $\begin{array}{l}\text { Data envelopment analysis (DEA), Fuzzy } \\
\text { Data, Fuzzy Screening System }\end{array}$ & $\begin{array}{l}\text { SL, } \\
\text { SS }\end{array}$ & [45]; [46] \\
\hline 7 & $\begin{array}{l}\text { Eleonora } \\
\text { Bottani }\end{array}$ & 2 & - & Analytic model, Fuzzy Model & SPL & [47]; [48] \\
\hline 8 & $\begin{array}{l}\text { Chong } \\
\mathrm{Wu}\end{array}$ & 2 & - & $\begin{array}{l}\text { systematic four-stage model based on } \\
\text { Dempster-Shafertheory, the improved non- } \\
\text { dominated sorting genetic algorithm-II } \\
\text { (NSGA-II), and thedecision-making trial and } \\
\text { evaluation laboratory (DEMATEL) method }\end{array}$ & SS & [49]; [50] \\
\hline 9 & $\begin{array}{l}\text { Ali } \\
\text { Esfandi }\end{array}$ & 2 & - & $\begin{array}{l}\text { resource dependence theory(RDT)lens, } \\
\text { structural equation modelling }(\mathrm{SEM}) \text { method }\end{array}$ & $\begin{array}{l}\text { FS, } \\
\text { SP }\end{array}$ & [3]; [51] \\
\hline
\end{tabular}




\begin{tabular}{llllllll}
\hline $\mathbf{1}$ & Adel 2 & - & Cross-efficiency & evaluation, & Data & FS, & [52]; [53] \\
$\mathbf{0}$ & Hatami & & envelopment & analysis & (DEA), Fuzzy data, SS & \\
& & Lexicographic & multi-objective & linear & \\
& & programming, Fuzzy & targets, Super- \\
& & & & \\
& & & &
\end{tabular}

As it is clearly seen in Table 1, the modules that the authors intrested in are SS and FS, which are supplier selection and Framework Structure for SSCM.

Table 2 presents the mathematical models, methods and tools which are used for SSCM, the number of papers and refrences of them.

Table 2: The papers for every mathematical models which are used in SSCM modeling

\begin{tabular}{|c|c|c|c|}
\hline Raw & $\begin{array}{l}\text { Mathematical methods and } \\
\text { models }\end{array}$ & $\begin{array}{l}\text { Num } \\
\text { bers } \\
\text { of } \\
\text { pa- } \\
\text { pers }\end{array}$ & Ref. \\
\hline 1 & AHP & 17 & [30]; [54]; [55]; [31]; [56]; [57]; [22]; [32]; [58]; [59]; [36]; [60]; [61]; [62]; [63]; [64] \\
\hline 2 & Analytic Model & 1 & [47] \\
\hline 3 & ANOVA & 1 & [65] \\
\hline 4 & ANP & 7 & [66]; [67]; [39]; [32]; [68]; [69]; [70] \\
\hline 5 & Artificial Intelligent & 2 & [71]; [72] \\
\hline 6 & Big Data Assessment & 3 & {$[73] ;[74] ;[75]$} \\
\hline 7 & Bi-level Programming & 3 & [76]; [77], [69] \\
\hline 8 & BMW & 4 & {$[78] ;[79] ;[80] ;[81]$} \\
\hline 9 & BOP & 2 & [82]; [42] \\
\hline 10 & Cluster Analysis & 3 & [73]; [83]; [84] \\
\hline 11 & CSF & 3 & [39]; [85]; [86]; \\
\hline 12 & DEA & 16 & [53]; [73]; [87]; [88]; [89]; [45]; [46] ; [90]; [91]; [92]; [75]; [93]; [94]; [95]; [61]; [63] \\
\hline 13 & Delphi & 7 & [39]; [96]; [32]; [97]; [98]; [99]; [100] \\
\hline 14 & DEMATEL & 11 & [101]; [50]; [67]; [102]; [7]; [103]; [32]; [104]; [105]; [69]; [106]; \\
\hline 15 & ELECTRE & 2 & [78]; [107]; \\
\hline 16 & EOQ & 1 & [108] \\
\hline 17 & EPQ & 1 & [108] \\
\hline 18 & ERM & 1 & [109] \\
\hline 19 & FMEA & 1 & [110] \\
\hline 20 & Fuzzy Theory & 41 & $\begin{array}{l}\text { [53]; [52]; [111]; [101]; [30]; [112]; [113]; [49]; [39]; [6]; [40]; [47]; [67]; [102]; [114]; [115]; [22]; [32]; } \\
\text { [79]; [109]; [116]; [97]; [45]; [46]; [98]; [117]; [69]; [118]; [119]; [120]; [121]; [122]; [100]; [94]; [123]; } \\
\text { [61]; [62]; [124]; [63]; [125]; [64] }\end{array}$ \\
\hline 21 & Game Theory & 4 & [126]; [127]; [128]; [129] \\
\hline 22 & Genetic Algorithm & 4 & [130]; [50]; [72]; [34] \\
\hline
\end{tabular}




\begin{tabular}{|c|c|c|c|}
\hline 23 & Gioia Methodology & 1 & [131]; \\
\hline 24 & Goal Programming & 9 & [132]; [133]; [125]; [134]; [135]; [92]; [59]; [89]; [67] \\
\hline 25 & Graph Theory & 3 & [52]; [136]; [137] \\
\hline 26 & Hessian Matrix & 1 & [138] \\
\hline 27 & Hybrid Method & 10 & [73]; [111]; [39]; [139]; [57]; [22]; [32]; [33]; [92]; [100] \\
\hline 28 & Hypotheses & 4 & [140]; [141]; [142]; [143]; \\
\hline 29 & IFS & 1 & [69] \\
\hline 30 & Integer Linear Programming & 10 & [40]; [139]; [114]; [77]; [144]; [60]; [133]; [132]; [145]; [146]; \\
\hline 31 & ISM & 10 & [147]; [66]; [39]; [7]; [27]; [137]; [148]; [149]; [150]; [86] \\
\hline 32 & KPI & 1 & [47] \\
\hline 33 & Likert Scale & 1 & [151]; \\
\hline 34 & MCDM & 13 & [111]; [112]; [147]; [31]; [39]; [114]; [32]; [69]; [152]; [153]; [62]; [63]; [18] \\
\hline 35 & MINLP & 2 & [40]; [114] \\
\hline 36 & MLH & 1 & [154] \\
\hline 37 & MRIO & 1 & [88] \\
\hline 38 & Multi Objective Program & 22 & $\begin{array}{l}\text { [53]; [130]; [155]; [113]; [156]; [146]; [157]; [139]; [57]; [26]; [33]; [34]; [158]; [105]; [59]; [159]; [160]; } \\
\text { [161]; [94]; [123]; [95]; [37] }\end{array}$ \\
\hline 39 & PLS-SEM & 4 & [162]; [140]; [163]; \\
\hline 40 & RDT & 1 & [3]; \\
\hline 41 & Rough Set Theory & 2 & [107]; [164]; \\
\hline 42 & Sampling & 2 & [165]; [166]; \\
\hline 43 & SEM & 9 & [38]; [162]; [147]; [49]; [140]; [167]; [98]; [163]; [168]; \\
\hline 44 & Simulation & 2 & [169]; [170]; \\
\hline 45 & VIKOR & 5 & [30]; [102]; [69]; [119]; [36] \\
\hline
\end{tabular}

The most notable feather of the table 2 concerns some papers and authors used several mathematical models and methods together for making a model or solving problems in SSCM. For example, majority of papers used the fuzzy logic method for normalizing variables, or balancing parameters and enablers in the mathematical models as primary method, then used another model such as Goal programming for finding the optimum solution [125];[59]; [67] or Multi Object Program [53]; [130]; [94] for best solution. Also, AHP method is used for weighting variables, priorities as an auxilary methods for definning variabled and normalizing them for using in the mathematical models, beside to AHP, authors offer another mathematical model for completed SSCM model like AHP-VIKOR [30]; AHP -MCDM and Gray Theory [31]; AHP-Multi Objective program [57]; and etc.

\subsection{Category four: The roles of parties in SSCM Modeling}

For SSCM modeling, there are different parties which are involving and have roles who are Stakeholders, Governments, People, Social, Environmet, Factories, Logistics Companies and resources. Figure 10 represents the different parties and the relative effects. 


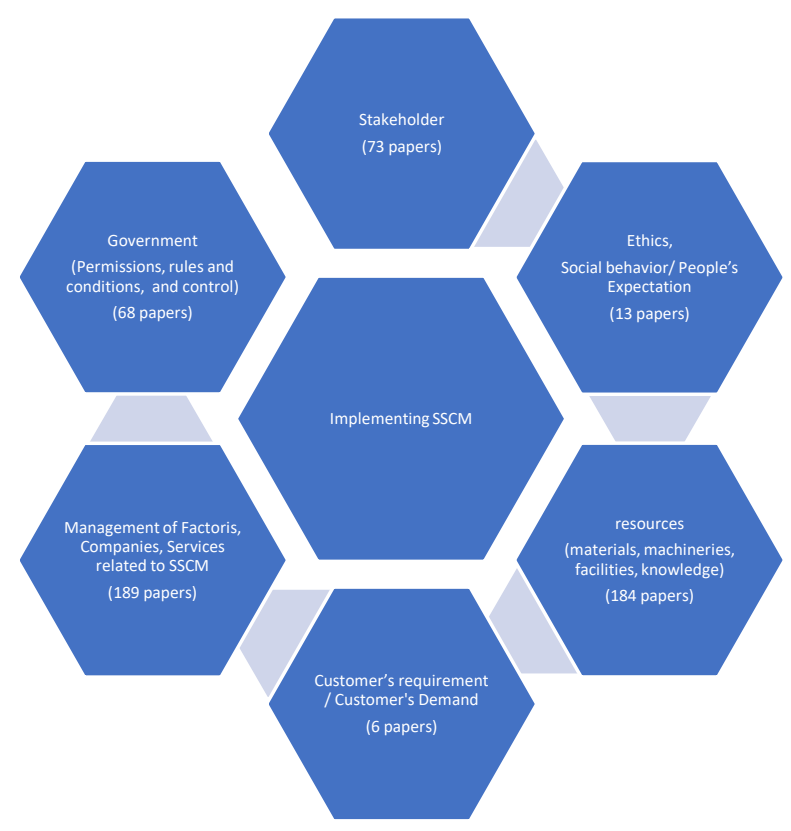

Figure 10: The parties which are involved for SSCM modeling

One of the main involving partners is Government who is responsible for Control environmental and social impacts. In 2015, The responsible representatives of 193 countries of the world held a meeting and set sustainable development goals till year 2030 [25]. The limitation of carbon cap and carbon credit is a good constraint for controlling carbon caps and protecting environment. Every country can make their own constraints for factories, companies, transportation and so on, and control the pollutions. The different researches are investigate how to control carbon cap through different partners and rules which are set by governments [51]; [107]; [4]. On the other hand, customer's demands are an important cause for producing the environmental unfriendly products (EUFP). For controlling the carbon cap and green environment, the training people for choosing the environmental friendly product (EFP) [34]; [107].

\section{Conculation and Sugesstions:}

Although gainning increased attention on SSCM, the using mathematical methods and models for solving problems and designning new models relative to SSCM frames and modules are increased. In this paper, we conducted a systematic litrature review to identify the current situation of using mathematical models and methods for SSCM and finding the gaps. The Gaps between the Current situation which are discussed in section three, and the ideal are divided in modules of SSCM, Partners who are involved in SSCM, Countries and area for SSCM and industries.

\section{1: SSCM Modules}

We divided the SSCM in eleven modules which are shown in Figure 7. We defined these modules with using different papers conclusions and contents and categorised them in eleven core of research in SSCM and named as modules of SSCM. The resulte of analysis papers and research contents showed that there is no balance for research in different modules. Some modules like SS (Supplier Selection) or FS (Frame work Structure) are evaluated in different papers and there are different mathematical models and methods for modeling these modules. However some modules like SR (Sustainable Recycling) and SPK (Sustainable Packaging) are needed more research. The new research is needed for evaluation the weight of every modules according to environmental impacts and social attention and how to optimum the current situation and gainning goals of sustainability in different modules.

\section{2: Involved partners in SSCM mathematical models}

After analysis the paper contents, we offer a model of different partners who have an important role in SSCM (Figure 10). With content analysis of papers, we found that the changing approach for customer's demand is needed. 
We suggest that the role of demand in designning products and EFP should be investigated. In the researches, the role of stakeholders and governments are more highlight. However other roles should be considered and need to add in the roles of SSCM models.

\section{3.: Countries or area of research}

As it is clearly seen in the Figure 4, the research in some countries are a few. According to united nation definition for sustainability [25], different countries have different goals for sustainability. There is a gap between modeling SSCM in different countries and the defined goals. Some countries need more research which are clear in figure 4 .

4.4: Industries as case study or implementing models

In the figure 5 ahows the industries which are investigated as case study or implementing SSCM models in them. As it is clearly seen, the heavy industries which have more weight on the sustainability [25] like casting, steel, and so on, need more research.

After analysis the gap between current situations and goals, we found to need more research on different modules of SSCM, different industries, different countries no matter developed or undevelopped and differend involved partners in SSCM. The analysis presented in this paper enabled the authors to define SSCM models in different modules and categorised in different mathematical models. These categorizes and gap analysis can be helped future researches and designning new models.

\section{Acknowledgment}

This research is funded by National Natural Science Foundation of China under Grand Number: 71832001. Also, thanks Department of Logistics and Electronic Commerce, Glorious Sun School of Business and Management, Shanghai Donghua University for supporting us in this project.

References

[1] S. Seuring and M. Müller, "From a literature review to a conceptual framework for sustainable supply chain management," Journal of Cleaner Production, vol. 16, no. 15, pp. 1699-1710, 2008.

[2] R. B. Sánchez-Flores, S. E. Cruz-Sotelo, S. Ojeda-Benitez and M. E. Ramírez-Barreto, "Sustainable Supply Chain Management-ALiterature Review on Emerging Economies," Sustainability, vol. 12, no. 17, pp. 1-27, 2020.

[3] E. Ali, Z. Yufeng and W. Glyn, "Sustainable supply chain management in emerging economies: Trade-offs between environmental and cost performance," Int. J.ProductionEconomics, vol. 181, no. Part B, p. 350-366, 2016.

[4] D. Köksal and J. S. a. M. Müller, "Social Sustainability in Apparel Supply Chains - The Role of the Sourcing Intermediary in a Developing Country," Sustainability, vol. 10, 2018.

[5] F. Jia, Z.-C. Laura, B. Adrian and R. Ximena, "Sustainable supply chain management in developing countries: An analysis of the literature," Journal of Cleaner Production, vol. 189, pp. 263-278, 2018.

[6] D. Kannan, A. B. L. d. S. Jabbour and C. J. C. Jabbour, "Selecting green suppliers based on GSCM practices: Using fuzzy TOPSIS applied to a Brazilian electronics company," European Journal of Operational Research, vol. 233, no. 2, p. 432-447, 2014. 
[7] H. Fang, B. Wang and W. Song, "Analyzing the interrelationships among barriers to greenprocurement in photovoltaic industry: An integrated method," Journal of Cleaner Production, vol. 249, p. 119408, 2020.

[8] J. S. a. T. A. Rinib, "A structural literature review on models and methods analysis of green supply chain management," Procedia Manufacturing, vol. 4, p. 291 - 299, 2015.

[9] M. A. N. Agi and S. F.-O. a. Ö. Hazır, "Game theory-based models in greensupply chain management: a review ofthe literature," International Journal of Production Research, 2020.

[10] C. Martins and M. Pato, "Supply chain sustainability: A tertiary literature review," Journal od Cleaner Production, vol. 225, pp. 995-1016, 2019.

[11] Zhang and G. Z. a. Yixiang, "Integration and consolidation in air freight shipment planning: An economic and environmental perspective," Journal of Cleaner Production, vol. 166, pp. 1381-1394, 2017.

[12] B. Li, W. Chen and C. X. a. P. Hou, "Impacts of government subsidies for environmental-friendly products in a dual-channel supply chain," Journal of Cleaner Production, vol. 171, pp. 1558-1576, 2018.

[13] B. Tundys and TomaszWi'sniewski, "The Selected Method and Tools for Performance Measurement in the Green Supply Chain-Survey Analysis in Poland," Sustainability, vol. 10, no. 2, pp. 1-26, 2018.

[14] P. Ahi and C. Searcy, "An analysis of metrics used to measure performance in green and sustainable supply chains," Journal of Cleaner Production, vol. 86, pp. 360-377, 2015.

[15] A. Rajeev, R. K. Pati, S. S. Padhi and K. Govindan, "Evolution of sustainability in supply chain management: A literature review," Journal of Cleaner Production, vol. 162, pp. 299-314, 2017.

[16] A. P. Barbosa-Póvoa, C. d. Silva and A. Carvalho, "Opportunities and challenges in sustainable supply chain: An operations research perspective," European Journal of Operational Research, vol. 268, pp. 399-431, 2018.

[17] R. A, R. K. Pati and S. S. Padhi, "Sustainable supply chain management in the chemical industry: Evolution, opportunities, and challenges," Resources, Conservation E Recycling, vol. 149, p. 275-291, 2019.

[18] Z. N. Ansari and R. Kant, "A state-of-art literature review reflecting 15 years of focus on sustainable supply chain management," Journal of Cleaner Production, vol. 142, pp. 2542-2543, 2017.

[19] B. Tundys, "Sustainable Supply Chain Management - Past, Present and future," RESEARCH PAPERS OF WROCLAW UNIVERSITY OF ECONOMICS AND BUSINESS, vol. 64, no. 3, pp. 187-207, 2020.

[20] F. Cucchiella and I. D'Adamo, "Issue on supply chain of renewable energy," Energy Conversion and Management, vol. 76, pp. 774-780, 2013.

[21] J. S. G. and N. Nagesha, "Cleaner Production: A brief literature review," Materials Today: Proceedings , vol. 5, pp. 17944-17951, 2018.

[22] K. Rashidi, A. Noorizadeh, D. Kannan and K. Cullinane, "Applying the triple bottom line in sustainable supplier selection:A meta-review of the state-of-the-art," Journal of Cleaner Production, vol. 269, 2020.

[23] L. M. Matos, R. Anholon, D. d. Silva, R. E. C. Ordo nez, O. L. G. Quelhas, W. L. Filho and L. A. d. Santa-Eulalia, "Implementation of cleaner production: A ten-year retrospective on benefits and difficulties found," Journal of Cleaner Production, vol. 187, pp. 409-420, 2018.

[24] L. Messmann, V. Zender, A. Thorenz and A. Tuma, "How to quantify social impacts in strategic supply chainoptimization: State of the art," Journal of Cleaner Production, vol. 257, 2020.

[25] D. o. E. a. S. A. United Nation, $09 \quad 2015 . \quad$ [Online]. Available: https://www.un.org/development/desa/disabilities/envision2030.html. 
[26] H. Ding, L. Wang and L. Zheng, "Collaborative mechanism on profit allotment and public health for a sustainable supply chain," European Journal of Operational Research, vol. 267, no. 2, pp. 478-495, 2018.

[27] H. Ding, Q. Liu and L. Zheng, "Assessing the economic performance of an environmental sustainable supply chain in reducing environmental externalities," European Journal of Operational Research, vol. 255, pp. 463-480, 2016.

[28] H. Ding, QilanZhao, ZhirongAn and OuTang, "Collaborative mechanism of a sustainable supply chain with environmental constraints and carbon caps," Int. J.ProductionEconomics.

[29] H. Ding, M. He and C. Deng, "Lifecycle approach to assessing environmental friendly product project with internalizing environmental externality," Journal of Cleaner Production, vol. 66, pp. 128-138, 2014.

[30] A. Awasthi, K. Govindan and S. Gold, "Multi-tier sustainable global supplier selection using a fuzzy AHP-VIKOR based approach," International Journal of Production Economics, vol. 195, pp. 106-117, 2018.

[31] D. Mathivathanan, K. Govindan and A. N. Haq, "Exploring the impact of dynamic capabilities on sustainable supply chain firm's performance using Grey-Analytical Hierarchy Process," Journal of Cleaner Production, vol. 147, pp. 637-653, 2017.

[32] G. Kannan, S. Madan and K. Devika, "Supplier selection based on corporate social responsibility practices," International Journal of Production Economics, vol. 200, pp. 353-379, 2018.

[33] G. Kannan, J. Ahmad and N. Vahid, "Designing a sustainable supply chain network integrated with vehicle routing: A comparison of hybrid swarm intelligence metaheuristics," Computers and Operations Research, vol. 110, pp. 220-235, 2019.

[34] G. Kannan, A.Jafarian, R.Khodaverdi and K. Devika, "Two-echelon multiple-vehicle location-routing problem with time windows for optimization of sustainable supply chain network of perishablefood," Int. J.ProductionEconomics, vol. 152, pp. 9-28, 2014

[35] B. Marcus, G. Kannan, S. Joseph and S. Stefan, "Quantitative models for sustainable supply chain management: Developments and directions," European Journal of Operational Research, vol. 233, pp. 299-312, 2014.

[36] L. Sunil, G. Kannan, K. Devika, M. Sachin Kumar and G. Chandra Prakash, "An integrated framework for sustainable supplier selection and evaluation in supply chains," Journal of Cleaner Production , vol. 140, pp. 1686$1698,2017$.

[37] S. Zeinab, R. Mina and G. Kannan, "A sustainable supply chain for organic, conventional agro-food products: The role of demand substitution, climate change and public health," Journal of Cleaner Production, vol. 194, pp. 564-583, 2018.

[38] M. Abbas, K. Devika, E. H. Robert, O. Seckin, A. Melfi and B. T. Erfan, "Evaluation of green and sustainable supply chain managementusing structural equation modelling: A systematic review of the state of the art literature and recommendations for future research," Journal of Cleaner Production Volume, vol. 249 , no. 3, 2020.

[39] K. Devika, "Role of multiple stakeholders and the critical success factor theory for the sustainable supplier selection process," International Journal of Production Economics, vol. 195, pp. 391-418, 2018.

[40] K. Devika, J. Alireza and V. Nourbakhsh, "Designing a sustainable closed-loop supply chain network based on triple bottom line approach: A comparison of metaheuristics hybridization techniques," European Journal of Operational Research, vol. 235, pp. 594-615, 2014.

[41] N. Daiane Mülling, L. Anna, S. Stefan and F. M. d. N. Luis, "Linking sustainability-oriented innovation to supply chain relationship integration," Journal of Cleaner Production, pp. 1-11, 2017. 
[42] S. Stefan, B.-A. Carolin and U. K. Raja, "Analyzing base-of-the-pyramid projects through sustainable supply chain management," Journal of Cleaner Production 212 (2019) 1086e1097, vol. 212, pp. 1086-1097, 2019.

[43] R. Tobias, B. Marcus and S. Stefan, "System dynamics modeling for sustainable supply chain management: A literature review and systems thinking approach," Journal of Cleaner Production, vol. 208, pp. 1265-1280, 2019.

[44] A. Payman, Y. J. Mohamad and S. Cory, "A comprehensive multidimensional framework for assessing the performance of sustainable supply chains," Applied Mathematical Modelling 40 (2016) 10153-10166, vol. 40, pp. 10153-10166, 2016.

[45] I. Mohammad, F. S. Reza and A. Kourosh, "How to assess sustainability of suppliers in volume discount context? A new data envelopment analysis approach," Transportation Research, vol. 51, no. Part D, pp. 102-121, 2017.

[46] I. Mohammad, F. S. Reza, A. Kourosh and S. Mohadeseh, "How to use fuzzy screening system and data envelopment analysis for clustering sustainable suppliers? A case study in Iran," Journal of Enterprise Information Management, 2020.

[47] B. Eleonora, C. G. Maria and R. Marta, "A Fuzzy Logic-Based Tool for the Assessment of Corporate Sustainability: A Case Study in the Food Machinery Industry," sustainability, 2017.

[48] Eleonora, L. T. Bottani, L. Isabella and C. Giorgia, "Economic and environmental sustainabilitydimensions of a fashion supply chain: Aquantitative model," Production Journal, 2020.

[49] W. Chong, L. Chuanlin, B. David and Z. Yi, "Partner selection in sustainable supply chains: A fuzzy ensemble learning model," Journal of Cleaner Production, vol. 275, no. 12, pp. 123-165, 2020.

[50] W. Chong, Z. Yi, P. Hubert and L. Chuanlin, "Construction of partner selection criteria in sustainable supplychains: A systematic optimization model," Expert Systems with Applications, vol. 158, no. 11, 2020.

[51] E. Ali, Z. Yufeng, W. Glyn and Z. Tao, "Governance pressures and performance outcomes of sustainable supply chain management e An empirical analysis of UK manufacturing industry," Journal of Cleaner Production , vol. 155, pp. 66-78, 2017.

[52] H.-M. Adel, J. A. Per, T. Madjid and K. Pegah, "A flexible cross-efficiency fuzzy data envelopment analysis model for sustainable sourcing," Journal of Cleaner Production, vol. 142, pp. 2761-2779, 2017.

[53] H.-M. Adel, E. Ali and L. Sebastián, "Fuzzy efficiency measures in data envelopment analysis using lexicographic multiobjective approach," Computers $\mathcal{E}$ Industrial Engineering, vol. 105, pp. 362-376, 2017.

[54] A. Azimifard, S. H. Moosavirad and S. Ariafar, "Selecting sustainable supplier countries for Iran's steel industry at three levels by using AHP and TOPSIS methods," Resources Policy, vol. 57, pp. 30-44, 2018.

[55] A. E. Guliyeva and M. Lis, "Sustainability Management of Organic Food Organizations: A Case Study of Azerbaijan," Sustainability, vol. 12, 2020.

[56] M. Ernesto, R. F. Javier, H.-E. Andrés and T. Duc, "An AHP-based multi-criteria model for sustainable supply chaindevelopment in the renewable energy sector," Expert Systems with Applications, vol. 150, 2020.

[57] A. Hamid, G. Yuhan, C. Alok and B. Jacqueline, "Sustainable agro-food supply chain design using two-stage hybrid multi-objective decision-making approach," Computers and Operations Research, vol. 89, pp. 369-384, 2018.

[58] B. MahathirMohammad, A. SyedMithun, K. Golam and P. SanjoyKumar, "Supply chain sustainability assessment with Dempster-Shafer evidence theory: Implications in cleaner production," Journal of Cleaner Production, vol. 237, 2019. 
[59] C. Renato, O. AngeloMárcio, P. S. O. Karla and M. FranciscoGaudêncio, "Integrated method combining analytical and mathematical models for the evaluation and optimization of sustainable supply chains: A Brazilian case study," Computers E Industrial Engineering, vol. 139, no. 1, 2020.

[60] A. Tülin and G. Zeynep, "Mathematical modelling of sustainable procurement strategies: three case studies," Journal of Cleaner Production, vol. 113, pp. 767-780, 2016.

[61] L. Yan, E. Claudia, Y.-L. Gwenola and P. Gaëlle, "A fuzzy decision tool to evaluate the sustainable performance of suppliers in an agrifood value chain," Computers $\mathcal{E}$ Industrial Engineering , vol. 127, pp. 196-212, 2019.

[62] S. YogeshKumar, Y. AlokKumar, K. M. Sachin and P. PravinP., "Ranking the Success Factors to Improve Safety and Security in Sustainable Food Supply Chain Management Using Fuzzy AHP," Materials Today: Proceedings , vol. 5, pp. 12187-12196, 2018.

[63] Y. Yun and Y. Wang, "Supplier Selection for the Adoption of Green Innovation in Sustainable Supply Chain Management Practices: A Case of the Chinese Textile Manufacturing Industry," Processes, vol. 8, 2020.

[64] X. Zhou, Q. Jindong, L. Jun and M. Luis, "Sustainable supplier selection based on AHPSort II in interval type-2 fuzzy environment," Information Sciences, vol. 483, pp. 273-293, 2019.

[65] P. Tamara, B.-P. Ana, K. Andrzej and C. Ana, "Quantitative indicators for social sustainability assessment of supply chains," Journal of Cleaner Production, vol. 180, pp. 748-768, 2018.

[66] D. Abhijeet, D. R. Rakesh, S. Vinay, N. Balkrishna, B. Bhaskar and G. shwini, "Evaluation of critical constructs for measurement of sustainable supply chainpractices in lean-agile," Business Strategy and the Environment, vol. 29, no. 3, 2020 .

[67] B.-T. Erfan, M. Abbas, D. Zahra, S. Mehdi and W. Gerhard-Wilhelm, "A novel hybrid method using fuzzy decision making andmulti-objective programming for sustainable-reliable supplierselection in two-echelon supply chain design," Journal of Cleaner Production, vol. 250, no. 3, 2020.

[68] H. Mohammad, A. Anjali and M. *, "Interpretive structural modeling-analytic network process integrated framework for evaluating sustainable supply chain management alternatives," AppliedMathematicalModelling, vol. 40, pp. 3671-3687, 2016.

[69] P. Patchara and T. Chunqiao, "A New Extension to a Multi-Criteria Decision-Making Model for Sustainable Supplier Selection under an Intuitionistic Fuzzy Environment," Sustainability, vol. 11, no. 4513, 2019.

[70] W. Xiaole, L. Xiangtong, D. Zhuoqian and D. Yuanwei, "A novel model used for assessing supply chain sustainability integrating the ANP and ER approaches and its application in marine ranching," Journal of Cleaner Production, vol. 279, no. 1, 2021.

[71] E. Frank and O. Bramwel, "Leveraging Digital Approaches for Transparency in Sustainable Supply Chains: A Conceptual Paper," Sustainability , vol. 12, no. 6129, 2020.

[72] D.-M. Jose-Antonio, P.-B. Rocio and A.-M. Jorge, "Designing the appearance of environmentally sustainable products," Journal of Cleaner Production, vol. 135, pp. 784-793, 2016.

[73] T. Akash, S. Arun and S. Simar Preet, "Integrated frame work for identifying sustainable manufacturing layouts based on big data, machine learning,meta-heuristic and data envelopment analysis," Sustainable Cities and Society, vol. 62 , no. 11,2020 .

[74] S. Malin, C. Ling, Z. Zhixia, F. Ron, L. Xi, W. Yutao and H. Donald, "How would big data support societal development and environmental sustainability? Insights and practices," Journal of Cleaner Production, vol. 142, pp. 489-500, 2017. 
[75] B. Taliva, F. Reza and S. Tahmoures, "Assessing sustainability of supply chains by double frontier network DEA: A big data approach," Computers and Operations Research, pp. 1-7, 2017.

[76] H. Che-Fu, "A bilevel programming model for corporate social responsibility collaboration in sustainable supply chain management," Transportation Research, vol. Part E73, pp. 84-95, 2015.

[77] K. Mazyar and C.-V. Jos e-Fernando, "A bi-level programming model for sustainable supply chain network design that considers incentives for using cleaner technologies," Journal of Cleaner Production, vol. 213, pp. 1035$1050,2019$.

[78] Y. Gunjan, L. Sunil, K. Suresh, S. Jakhar, K. Mangla and P. Dhiraj, "A framework to overcome sustainable supply chain challengesthrough solution measures of industry 4.0 and circulareconomy: An automotive case," Journal of Cleaner Production, vol. 254, no. 5, 2020.

[79] M. Amiri, M. Hashemi-Tabatabaei, M. Ghahremanloo, M. Keshavarz-Ghorabaee, E. K. Zavadskas and A. Banaitis, "A new fuzzy BWM approach forevaluating and selecting a sustainablesupplier in supply chain management," International Journal of Sustainable Development E World Ecology, 2020.

[80] K. WanNurul, WanAhmad, R. Jafar, S. Saman and L. Tavasszy, "Evaluation of the external forces affecting the sustainability of oil and gas supply chain using Best Worst Method," Journal of Cleaner Production, vol. 153, pp. 242-252, 2017.

[81] A. Saima, E. Rafid, H. Tasmiah, A. SyedMithun, M. Md. Abdul and K. Sanjoy, "Environmental dimension in sustainable supply chain management: Framework and literature review," International Journal of Advanced and Applied Sciences, 7(8) 2020, Pages: 74-90, vol. 7, no. 8, pp. 74-90, 2020.

[82] B. JuliaC., R. Eugenia and P. Darima, "Sustainable supply chain models for base of the pyramid," Journal of Cleaner Production 162 (2017) S107eS120, vol. 162, pp. S107-S120, 2017.

[83] M. Roya and B. Markus, "A configuration of sustainable sourcing and supply management strategies," Journal of Purchasing E Supply Management, vol. 23, pp. 137-151, 2017.

[84] O. UalisonRebulade, E. LucianoSouza, S. IsabeleRochada, S. IaslinNostorioda and M. Henrique, "A systematic literature review on green supply chain management: Research implications and future perspectives," Journal of Cleaner Production 187 (2018) 537e561, vol. 187, pp. 537-561, 2018.

[85] G. J€org H., S. Joerg and S. Joseph, "Interrelationships amongst factors for sub-supplier corporate sustainability standards compliance: An exploratory field study," Journal of Cleaner Production, vol. 203, pp. 240-259, 2018.

[86] D. Rakesh, N. Balkrishna and B. Bhaskar, "To identify the critical success factors of sustainable supply chain management practices in the context of oil and gas industries: ISM approach," Renewable and Sustainable Energy Reviews, vol. 68, pp. 33-47, 2017.

[87] B. Elahe and F. Reza, "Developing a novel model of data envelopment analysis-discriminant analysis for predicting group membership of suppliers in sustainable supply chain," Computers and Operations Research 89 (2018) 348-359, vol. 89, pp. 348-359, 2018.

[88] H. Wang, P. Chen, W. Qunwei and P.Zhou, "Innovative applications of O.R. Assessing sustainability performance of global supply chains: Aninput-output modeling approach," European Journal of Operational Research, vol. 285, no. 1, pp. 393-404, 2020.

[89] S. Hadi, Y. Saeed and F. Reza, "Future planning for benchmarking and ranking sustainable suppliers using goal programming and robust double frontiers DEA," Transportation Research, vol. Part D50, pp. 129-143, 2017. 
[90] N. Mohammad, F. Reza and K. Reza, "A data envelopment analysis approach by partial impacts between inputs and desirable-undesirable outputs for sustainable supplier selection problem," Industrial Management $\mathcal{E}$ Data Systems, 2020.

[91] H. S.Motevali, T. S.A. and R. Ghasemi, "An integrated approach for performance evaluation in sustainable supply chain networks (with a case study)," Journal of Cleaner Production 137 (2016) 579e597, vol. 137, pp. 579-597, 2016.

[92] Y. Saeed, S. Roya, F. Reza and P. MirSaman, "A robust fuzzy possibilistic programming for a new network GPDEA model to evaluate sustainable supply chains," Journal of Cleaner Production, vol. 166, pp. 537-549, 2017.

[93] J. Xiang, W. Jie and Z. Qingyuan, "Eco-design of transportation in sustainable supply chain management: A DEAlike method," Transportation Research, vol. Part D 48, pp. 451-459, 2016.

[94] Z. Xiaoyang, P. Witold, K. Yunxin and Z. Zhe, "Type-2 fuzzy multi-objective DEA model: An application tosustainable supplier evaluation," Applied Soft Computing, vol. 46, pp. 424-440, 2016.

[95] W. Yadong, S. Quan, H. Qiwei, Y. Zhifeng, B. Yongsheng and G. Chiming, "An efficiency sorting multi-objective optimization framework for sustainable supply network optimization and decision making," Journal of Cleaner Production, vol. 272, no. 11, 2020.

[96] R. Hendrik and S. David, "Key themes and research opportunitie sin sustainable supply chain management identification andevaluation," Omega, vol. 66, pp. 195-211, 2017.

[97] T. Ming-Lang, T. ThiPhuong, K.-J. Wu, R. Raymond and D. Tat, "Exploring sustainable seafood supplychain management based on linguisticpreferences: collaboration in the supplychain and lean management driveeconomic benefits," International Journal of Logistics Research and Applications, 2020.

[98] B. Nejah, "Green supplier selection using fuzzy Delphi method for developing sustainable supply chain," Decision Science Letters, vol. 10, 2021.

[99] N. Omid, K. Ali and M. Saber, "Evaluation of sustainable supply chain management performance: Dimensions and aspects," Sustainable Development, vol. 28, no. 1, pp. 1-12, 2019.

[100] B. Tat-Dat, T. FengMing, T. Ming-Lang, T. RaymondR., D. S. Krista and K. L. Ming, "Sustainable supply chain management towards disruption and organizational ambidexterity: A data driven analysis," Sustainable Production and Consumption 26 (2021) 373-410, vol. 26, pp. 373-410, 2021.

[101] K. Anil, M. Md. Abdul, R. SyedAbdul, G.-R. JoseArturo, T. Mrinal and K. Yiğit, "Behavioral factors on the adoption of sustainable supply chainpractices," Resources, Conservation and Recycling, vol. 158, 2020.

[102] Z. Fuli, W. Xu, K. Ming and H. L. L. Yandong, "Sustainable recycling partner selection using fuzzy DEMATELAEWFVIKOR: A case study in small-and-medium enterprises (SMEs)," Journal of Cleaner Production, vol. 196, pp. 489-504, 2018.

[103] S. Jing, T. Marco and O.-M. Miguel, "A grey-DEcision-MAking Trial and Evaluation Laboratory (DEMATEL) analysis on the barriers between environmentally friendly products and consumers: practitioners' viewpoints on the European automobile industry," Journal of Cleaner Production, vol. 112, pp. 3185-3194, 2016.

[104] K. Mahtab, S. Sara and S. Joseph, "Blockchain technology and the sustainable supply chain: Theoretically exploring adoption barriers," Int. J. Production Economics, vol. 231, 2021.

[105] Y. Morteza, C. Prasenjit, K. Edmundas and H. Sarfaraz, "Integrated QFD-MCDM framework for green supplier selection," Journal of Cleaner Production, vol. 142, no. Part 4, pp. 3728-3740, 2017. 
[106] W. Zhigang, K.Mathiyazhagan, X. Lei and D. Ali, "A decision making trial and evaluation laboratory approach to analyze the barriers to Green Supply Chain Management adoption in a food packaging company," Journal of Cleaner Production, vol. 117, pp. 19-28, 2016.

[107] L. Huiyun, J. Shaojun, S. Wenyan and M. Xinguo, "A framework to overcome sustainable supply chain challengesthrough solution measures of industry 4.0 and circulareconomy: An automotive case," Sustainability, vol. 10, 2018.

[108] A. Noraida, H. Hawa, R. Rizauddin and M. Zulkifli, "An inventory model of supply chain disruption recovery with safety stock and carbon emission consideration," Journal of Cleaner Production, vol. 197, pp. 1011-1021, 2018.

[109] A. Majid, J. Mostafa, F. Reza and M. SeyedMostafa, "A new fuzzy DEA model for evaluation of efficiency and effectiveness of suppliers in sustainable supply chain management context," Computers E Operations Research, vol. 54, pp. 274-285, 2015.

[110] V. Fatemeh and R. Donya, "Sustainability risk management in the supply chain of telecommunication companies: A case study," Journal of Cleaner Production 203 (2018) 53e67, vol. 203, pp. 53-67, 2018.

[111] F. Alireza, U. Ezutah, N. Siti, Y. Kuan and N. Samira, "A decision support model for sustainable supplier selection in sustainable supply chain management," Computers $\mathcal{E}$ Industrial Engineering, vol. 105, pp. 391-410, 2017.

[112] M. Aydin, P. Ehsan and V. Rene, "An integrated fuzzy MCDM approach to improve sustainable consumption and production trends in supply chain," Sustainable Production and Consumption, vol. 16, pp. 99-109, 2018.

[113] B. Adenso-Díaz, S.Lozano and P.Moreno, "How the environmental impact affects the design of logistics networks based on cost minimization," Transportation Research, vol. D 48, pp. 214-224, 2016.

[114] K. Harpreet, P. Surya, A.-R. Jose and M. Nishikant, "Sustainable stochastic production and procurement problem for resilient supply chain," Computers $\mathcal{E}$ Industrial Engineering , vol. 139, 2020.

[115] F. John and S. Sheila, "Integrating fuzzy analytic hierarchy process into a multi-objective optimisation model for planning sustainable oil palmvalue chains," Food and Bioproducts Processing, vol. 19, pp. 48-74, 2020.

[116] H. Md Maruf, K. Sanjoy, A. Omid and A. Mohammed, "Dynamic sustainability requirements of stakeholders and thesupply portfolio," Journal of Cleaner Production, vol. 255, 2020.

[117] T. Ozden, M. Gazi, K. Elif and S. M.Gupta, "Environmentally Concerned Logistics Operations in Fuzzy Environment: A Literature Survey," Logistics, vol. 1, no. 4, 2017.

[118] G. Pezhman, D. Ahmad and H. Cathal, "Sustainable supplier performance scoring using audition check-list based fuzzy inference system: A case application in automotive spare part industry," Computers E Industrial Engineering, vol. 105, pp. 12-27, 2017.

[119] M. Phommaly, S. Hua, L. Shu-Min and L. Hu-Chen, "An Extended Picture Fuzzy VIKOR Approach for Sustainable Supplier Management and Its Application in the Beef Industry," Symmetry, vol. 11, no. 468, 2019.

[120] R. Pratibha, R. Arunodaya, K. Raghunathan, M. Abbas, C. Fausto, S. Kattur and B. Karthikeyan, "Hesitant Fuzzy SWARA-Complex Proportional Assessment Approach for Sustainable Supplier Selection (HF-SWARACOPRAS)," Symmetry, vol. 1152, p. 12, 2020.

[121] S. Ravi, C. Divya and J. Sanjay, "An integrated risk assessment model: A case of sustainable freight transportation systems," Transportation Research, vol. Part D 63, pp. 662-676, 2018.

[122] C. Sumit and K. Neeraj, "Development of a framework toimprove supply chain performancethrough e-business and sustainabilityenablers: An emerging economyperspective," Management of Environmental Quality, vol. 31, no. $5,2020$. 
[123] Z. Xin, Z. Gang, Q. Yingxiu and L. Botang, "A Robust Fuzzy Optimization Model for Closed-Loop Supply Chain Networks Considering Sustainability," Sustainability, vol. 11, no. 5726, 2019.

[124] L. Yuan-Hsu and T. Ming-Lang, "Assessing the competitive priorities within sustainable supply chain management under uncertainty," Journal of Cleaner Production , vol. 112, pp. 2133-2144, 2016.

[125] A. Zainab, A. Syed and J. Shakeel, "An uncertain model for integrated production-transportation closed-loop supply chain network with cost reliability," Sustainable Production and Consumption, vol. 17, pp. 298-310, 2019.

[126] R. Alok, B. Indranil and K. Samir, "Designing supply contracts for the sustainable supply chain using game theory," Journal of Cleaner Production, vol. 185, pp. 275-284, 2018.

[127] D. Bisheng, L. Qing and L. Guiping, "Coordinating Leader-Follower Supply Chain with Sustainable Green Technology Innovation on Their Fairness Concerns," Int. J. Environ. Res. Public Health, vol. 14, no. 1357, 2017.

[128] E. Shekarian, "A review of factors affecting closed-loop supply chain models," Journal of Cleaner Production 253 (2020) 119823, vol. 253, no. 119823, 2020.

[129] Z. Wenge and H. Yuanjie, "Green product design in supply chains under competition," European Journal of Operational Research, vol. 258, pp. 165-180, 2017.

[130] A. Ali, S. Farideh, Y. Reza, H. Jafar and M. Abolhassan, "Evolutionary multi-objective optimization of environmental indicators of integrated crude oil supply chain under uncertainty," Journal of Cleaner Production , vol. 152, pp. 295-311, 2017.

[131] C. Rosanna and A. James, "The role of intermediaries in establishing a sustainable supply chain," Journal of Purchasing and Supply Management, vol. 26, no. 2, 2020.

[132] G. Zahra and Q. Xu, "Mathematical Model for Sustainable Production Line," International Business Research, vol. 14, no. 1, pp. $1-18,2021$.

[133] G. Zahra and Q. Xu, "A mathematical SSCM model for minimizing the CO2 emission with considering economic goals and social benefits," Archives of Business Research, vol. 6, no. 3, pp. 167-180, 2018.

[134] I. Sonia, H. Young and S. Muhammad, "Sustainable and Resilient Supply Chain Network Design under Disruption Risks," Sustainability, vol. 6, pp. 6666-6686, 2014.

[135] S.-C. Tseng and H. Shiu-Wan, "A strategic decision-making model considering the social costs of carbon dioxide emissions for sustainable supply chain management," Journal of Environmental Management, vol. 133, pp. 315-322, 2014.

[136] N. Gopalakrishnan, S. Tuhin, K. Rupesh, G. Vipul, G. Anand and V. Mani, "Assessment of systemic greenness: a casestudy of tyre manufacturing unit," The Management of Operations Volume 31, 2020 - Issue 11-12, vol. 31, no. 11$12,2020$.

[137] S. K.T., G. Angappa and D. Rameshwar, "Explaining sustainable supply chain performance using a total interpretive structural modeling approach," SUS TA I N A L E P R O DUCTI ONANDCONSUMPTI O N , vol. 12, pp. 104-118, 2017.

[138] B. Zahra and H. Jafar, "A mathematical model for green supply chain coordination with substitutable products," Journal of Cleaner Production, vol. 145, pp. 232-249, 2017.

[139] F. Goodarzian, H. Hosseini-Nasab and M.B.Fakhrzad, "A Multi-objective Sustainable Medicine Supply Chain Network Design Using a Novel Hybrid Multi-objective Metaheuristic Algorithm," International Journal of Engineering, Basics, vol. 33, no. 10, pp. 1986-1995, 2020. 
[140] H. MuhammadShahid, R. Waseem, H. Khan, F. Waseem, M. JunaidHasheem and Y. Shi, "Process Innovation as a Moderator Linking Sustainable Supply Chain Management with Sustainable Performance in the Manufacturing Sector of Pakistan," Sustainability , vol. 12, no. 2303, 2020.

[141] H. Kim and C. WonLee, "The Effects of Customer Perception and Participation in Sustainable Supply Chain Management: A Smartphone Industry Study," Sustainability , vol. 10, no. 2271, 2018.

[142] T. Lee and H. Nam, "An Empirical Study on the Impact of Individual and Organizational Supply Chain Orientation on Spply Chain Management," The Asian Journal of Shipping and Logistics, vol. 32, no. 4, pp. 249-255, 2016.

[143] Y. Lu, C. Zhao, L. Xu and L. Shen, "Dual Institutional Pressures, Sustainable Supply Chain Practice and Performance Outcome," Sustainability , vol. 10, no. 3247, 2018.

[144] T. VanTran, H. Schnitzer, G. Braunegg and H. ThanhLe, "Development of an optimization mathematical model by applying an integrated environmental indicator for selecting alternatives in cleaner production programs," Journal of Cleaner Production, vol. 154, pp. 295-308, 2017.

[145] C. VergaraValderrama, E. Santibanez-González, B. Pimentel, A. Candia-Véjar and L. Canales-Bustos, "Designing an environmental supply chain network in the mining industry to reduce carbon emissions," Journal of Cleaner Production, vol. 254, 2020.

[146] C. Arampantzi and I. Minis, "A new model for designing sustainable supply chain networks and its application to a global manufacturer," Journal of Cleaner Production, vol. 156, pp. 276-292, 2017.

[147] B. B.Gardas, R. D.Raut and B. Narkhede, "Determinants of sustainable supply chain management: A case study from the oil and gas supply chain," Sustainable Production and Consumption, vol. 17, no. 2019, pp. $241-253,2019$.

[148] M. K. Lim, M.-L. Tseng, K. HuaTan and T. DatBui, "Knowledge management in sustainable supply chain management: Improving performance through an interpretive structural modelling approach," Journal of Cleaner Production, vol. 162, pp. 806-816, 2017.

[149] N. Bhanot, P. V. Rao and S. Deshmukh, "An integrated approach for analysing the enablers and barriers of sustainable manufacturing," Journal of Cleaner Production, vol. 142, pp. 4412-4439, 2017.

[150] P. Jia, A. Diabat and K.Mathiyazhagan, "AnalyzingtheSSCMpracticesintheminingandmineralindustryby ISM approach," Resources Policy, vol. 46, pp. 76-85, 2015.

[151] M. Asad, R. Naseer, M. Ashfaq, S. Hassan, A. Abbas, A. Razzaq, M. Mehdi, A. Ariyawardana and M. Anwar, "Critical Issues at the Upstream Level in Sustainable Supply Chain Management of Agri-Food Industries: Evidence from Pakistan's Citrus Industry," Sustainability 2019, vol. 11, no. 1326, 2019.

[152] P. DosSantos, S. MirandaNeves, D. OrnaghiSant'Anna, C. HenriqueOliveira and H. DuarteCarvalho, "The analytic hierarchy process supporting decision making for sustainable development: An overview of applications," Journal of Cleaner Production, vol. 212, pp. 119-138, 2019.

[153] V. BatistaSchramm, L. Priscila, B. Cabral and F. Schramm, "Approaches for supporting sustainable supplier selection - A literature review," Journal of Cleaner Production Volume, vol. 273, no. 10, 2020.

[154] V. Mani, A. Gunasekaran and C. Delgado, "Enhancing supply chain performance through supplier social sustainability: An emerging economy perspective," International Journal of Production Economics , vol. 195, pp. 259$272,2018$. 
[155] A. Chaabane, A. Ramudhin and M. Paquet, "Designing and Evaluating Sustainable Supply Chains: A Carbon Market Oriented Approach," in Proceedings of the 13th IFAC Symposium on Information Control Problems in Manufacturing, Moscow, 2009.

[156] B. Mota, M. I. Gomes, A. Carvalho and A. Barbosa-Povoa, "Towards supply chain sustainability: economic, environmental and social design and planning," Journal of Cleaner Production, vol. 105, no. 15, pp. 14-27, 2015.

[157] D. Varshney, P. Mandade and Y. Shastri, "Multi-objective optimization of sugarcane bagasse utilization in an Indian sugar mill," Sustainable Production and Consumption, vol. 18, pp. 96-114, 2019.

[158] M. Pishvaee, J. Razmi and S. Torabi, "An accelerated Benders decomposition algorithm for sustainable supply chain network design under uncertainty: A case study of medical needle and syringe supply chain," Transportation Research, Logistics and Transportation review, vol. Part E 67, no. 7, pp. 14-38, 2014.

[159] S. U. K. Rohmer, J. C. Gerdessen and G. D. H. Claassen, "Sustainable supply chain design in the food system with dietary considerations: A multi-objective analysis," European Journal of Operational Research 273 (2019) 1149-1164, vol. 273, no. 3, pp. 1149-1164, 2019.

[160] S. Rohmer, J. Gerdessen and G. Claassen, "Sustainable Supply Chain Design in the Food System with Dietary Considerations: A multi-objective Analysis," Journal of Operational Research, vol. 273, no. 3, pp. 1149-1164, 2018.

[161] T. Vafaeenezhada, R. Tavakkoli-Moghaddama and N. Cheikhrouhoud, "Multi-objective mathematical modeling for sustainable supply chain management in the paper industry," Computers $\mathcal{E}$ Industrial Engineering, vol. 135, pp. 1092-1102, 2019.

[162] B. Flygansvær, R. Dahlstrom and A. Nygaard, "Exploring the pursuit of sustainability in reverse supply chains for electronics," Journal of Cleaner Production, vol. 189, pp. 472-484, 2018.

[163] N. Hamia, M. RazaliMuhamadb and Z. Ebrahimb, "The Impact of Sustainable Manufacturing Practices and Innovation Performance on Economic Sustainability," Procedia CIRP, vol. 26, pp. 190-195, 2015.

[164] J. Li, H. Fang and W. Song, "Sustainability evaluation via variable precision rough set approach: A photovoltaic module supplier case study," Journal of Cleaner Production, vol. 192, pp. 751-765, 2018.

[165] M. Kostera, B. Vos and R. Schroeder, "Management innovation driving sustainable supply management Process studies in exemplar MNEs," BRQ Business Research Quarterly (2017) 20, 240---257, vol. 20, no. 4, pp. 240-257, 2017.

[166] Muchaendepia, C. Mbowab, J. Kanyepec and M. Mutingid, "Challenges faced by the mining sector in implementing sustainable supply chain management in Zimbabwe," Procedia Manufacturing 33 (2019) 493-500, vol. 33, pp. 493-500, 2019.

[167] J. Hong, Y. Zhang and M. Ding, "Sustainable supply chain management practices, supply chain dynamic capabilities, and enterprise performance," Journal of Cleaner Production, vol. 172, no. 1, pp. 3508-3519, 2018.

[168] Y. Agan, C. Kuzey, M. FatihAcar and A. Açıkg€oz, "The relationships between corporate social responsibility, environmental supplier development, and firm performance," Journal of Cleaner Production, vol. 112, no. Part 3, pp. 1872-1881, 2016.

[169] J. Oliveiraa, M. Jinc, R. Limaa, J. Kobzac and J. Montevechia, "The role of simulation and optimization methods in supply chain risk management: Performance and review standpoints," Simulation Modelling Practice and Theory , vol. 92, pp. 17-44, 2019.

[170] P. H. a-Dabrowska and K. Grzybowska, "Simulation Modeling of the Sustainable Supply Chain," Sustainability, vol. 12 , no. $6007,2020$. 
